\title{
THE INFLUENCE OF MINERAL METABOLISM UPON NEPHROTIC EDEMA 1
}

\author{
By WILLIAM S. HOFFMAN ${ }^{2}$ aNd WILBER E. POST \\ (From the Department of Medicine, Rush Medical College of the University \\ of Chicago, Chicago)
}

(Received for publication December 5, 1932)

The importance of low serum protein concentration in the pathogenesis of the type of edema seen in chronic nephritis, nephrosis, and " nutritional edema" is now so fully recognized that any effort to reproduce the evidence in its favor is superfluous. An extensive bibliography may be found in the recent papers by Leiter (1) and Loeb et al. (2) which enumerate the many contributions made to corroborate the concept first postulated by Starling (3) in 1896 and applied to nephrosis by Epstein (4) in 1917. These investigators maintain that the amount of fluid in the extracellular spaces in contact with blood capillaries is dependent upon the balance between the hydrostatic pressure within the capillaries and the osmotic pressure exerted by the serum proteins (the so-called oncotic pressure), and that in nephrosis the lowered concentration of serum protein so disturbs the balance between filtration and resorption of fluid that there is an accumulation of fluid in the extracellular spaces, which accumulation, when clinically evident, constitutes edema. Moore and Van Slyke (5) and Peters et al. (6) have found that the tendency to edema begins when the total serum protein concentration falls below 5.0 grams per cent or when the albumin concentration falls below 2.5 grams per cent.

In spite of all recent corroboration of this theory, and in spite of the evidence against Widal's (7) alternative theory of the inability of the kidney to excrete chlorides in cases of nephrotic edema, there are many observations which indicate that numerous other factors are concerned with both the presence and the extent of the edema. Many of these factors are discussed in the recent paper by Loeb et al. (2). These authors reaffirm the theory of Starling and Epstein, and further add that the extent of the edema is dependent upon the quantity of $\mathrm{NaCl}$ and water required to be filtered through the tissue spaces in order to maintain the normal osmotic relationship of the body fluids. They are, however, unable to offer any explanation for the frequent diuretic effect of $\mathrm{KCl}, \mathrm{NH}_{4} \mathrm{Cl}$ or $\mathrm{CaCl}_{2}$, or of the lack of diuretic effect of these ions in other cases. 1932.

1 Presented before the Central Society for Clinical Research, November 4,

${ }^{2}$ National Research Council Fellow in Medicine, 1931 and 1932. 
The present investigation was aimed to attack some of these problems, especially the role played by the various mineral ions in the production or remission of edema. For this purpose, four patients with varying clinical pictures, but all with " nephrotic" type of edema, were carefully studied in prolonged metabolic balance experiments. The case histories of these patients are summarized at the end of this paper.

\section{METHODS}

The patients were placed on diets of high protein, high carbohydrate, low fat, neutral ash, and low sodium chloride. The food was identical each day, and the fluid intake constant for any period. When sodium chloride or potassium chloride was given in addition to the diet, the estimated quantity for the day was placed in a salt-shaker and was used with the food of that day. Ammonium chloride was administered in solution after meals. Calcium gluconate (Sandoz) was given by intravenous injection, each ampoule containing $100 \mathrm{mgm}$. of calcium.

The urine for each 24 hours was collected and preserved, with the aid of toluene, in cork-stoppered bottles on ice. The stools were analyzed in one case only. In all cases, there were daily bowel movements, with no watery stools or diarrhea. The stools for analysis were collected in three-day periods in one vessel.

The urine was analyzed for basic constituents by the system outlined by Hoffman (8). In this method, from a single filtrate from the urine, total base, calcium, and sulfates were determined. From an aliquot of the dissolved ash used for fixed base determination, potassium was estimated by the method of Jacobs and Hoffman (9). Magnesium was determined in the filtrate from calcium by a slight modification of the method of Denis (10). Sodium was calculated from the difference between total base and the sum of potassium, calcium and magnesium. A trichloroacetic acid filtrate of the urine was used for Fiske and Subbarow's (11) determination of phosphate, and for the estimation of nonprotein nitrogen by the macro-Kjeldahl method. Chlorides were determined in the urine by the method of Van Slyke (12).

The blood was analyzed by similar methods. The serum was analyzed directly for potassium by the method of Jacobs and Hoffman (9), for calcium by that of Tweedy and Koch (13), for magnesium by that of Denis (10). Total base was determined on a phosphate-free, protein-free filtrate obtained from the serum by the method of Hoffman (14). In this method, coagulation by heat of the proteins of serum (diluted 25 times) is effected at the iso-electric point with the simultaneous precipitation of phosphates by ferric chloride and ammonium acetate. The results obtained on normal serum are probably about one per cent too high because of a slight evaporation of the hot liquid and because of the slight change in volume when the proteins are precipitated. The average value for normal serum was 156 milliequivalents per liter, as compared with 154 when the modified Fiske (15) method described by Peters and Van Slyke (16) was used on the same serum. These values are from 3 to 5 milliequivalents higher than those in which the original Stadie and Ross (17) technique was used.

The nonprotein nitrogenous constituents as well as glucose were analyzed by the Folin-Wu (18) methods, using, however, Koch and McMeekin's (19) peroxide oxidation for both the nonprotein nitrogen and the protein fractions obtained from the serum by Howe's (20) technique. Carbon-dioxide combining power was determined by Van Slyke and Cullen's (21) gasometric method. 
In the study of the last two patients, the distribution of the potassium between red cells and serum was determined as part of a systematic investigation of this distribution by Hoffman and Jacobs (22). The methods used as well as the results obtained are incorporated in their paper.

The food was analyzed by drying at $105^{\circ} \mathrm{C}$. for three days, weighing, pulverizing thoroughly in a mortar, sampling, and wet ashing an aliquot with $\mathrm{H}_{2} \mathrm{SO}$. and $\mathrm{HNO}_{3}$ in a Kjeldahl flask until the clear white solution solidified on cooling. The residue was dissolved in water and made up to $500 \mathrm{cc}$. An aliquot was ashed in a platinum crucible to remove the excess $\mathrm{H}_{2} \mathrm{SO}_{4}$, dissolved again, and analyzed for calcium, magnesium, phosphate and total base. The stools were similarly analyzed. The amount of sodium and potassium in the stools was negligibly small. Chloride was determined after digesting an aliquot of the dried, powdered food with $\mathrm{NaOH}$ for 24 hours in a steam bath.

The following is a sample of diet used: Lean meat (beef and chicken), 200 grams; cottage cheese, salt free, 100 grams; butter, salt free, 15 grams; milk, 200 grams; bread, salt free, 120 grams; celery, 75 grams; lettuce, 75 grams; beets, 75 grams; carrots, 75 grams; potatoes, 150 grams; orange juice, 200 grams; peaches, 75 grams; apples, 100 grams. Total carbohydrate, 172 grams; protein, 111 grams; fat, 71 grams; calories, 1770. Sodium, 1.42 grams; potassium, 2.74 grams; calcium, .52 gram ; magnesium, .19 gram; chlorine, 2.70 grams.

The first two patients studied (Cases I and II) were entirely cooperative. No food was left uneaten. The patients remained practically at all times in bed. The observations were carried out in the autumn and winter, and there was every indication that the fluid and salt losses from the skin and lungs were, for all purposes, nearly constant. However, the last two patients were studied in the summer time, during which there were days in which the temperature reached $100^{\circ} \mathrm{F}$., causing the obvious tremendous losses of fluid and salts in the perspiration. Besides, one of these patients was so ill and so uncomfortable because of his 70 pounds or more of edema fluid that it was impossible for him to cooperate completely. In these two cases, then, though urinary analyses were carried out, no balance studies were made.

\section{RESULTS}

Case $I$. The first patient had a moderately severe case of clinical nephrosis without any evidence of vascular or glomerular damage. $\mathrm{He}$ responded well to the diet and in nine days lost 18 pounds of fluid. After four days without edema, he was given, in addition to his constant diet, 10 grams of $\mathrm{NaCl}$ daily. He immediately began to retain fluid and gained 8 pounds in five days. At this stage, $\mathrm{NaCl}$ was removed and 6 grams of $\mathrm{KCl}$ substituted daily. The patient again lost the edema fluid by diuresis. In a second study, begun after the patient had been home for two weeks and had again taken on some edema fluid, the response to the dietary management was similar. He again gained in weight on addition of $\mathrm{NaCl}$ to his diet, with visible edema, and lost it after the removal of $\mathrm{NaCl}$. Calcium gluconate given intravenously at this period did not at all hasten the diuresis. As the experimental study progressed, the patient improved clinically very rapidly. His appetite, which at the onset was so poor as to necessitate a diet of 1500 calories, became so ravenous that he was continually hungry 


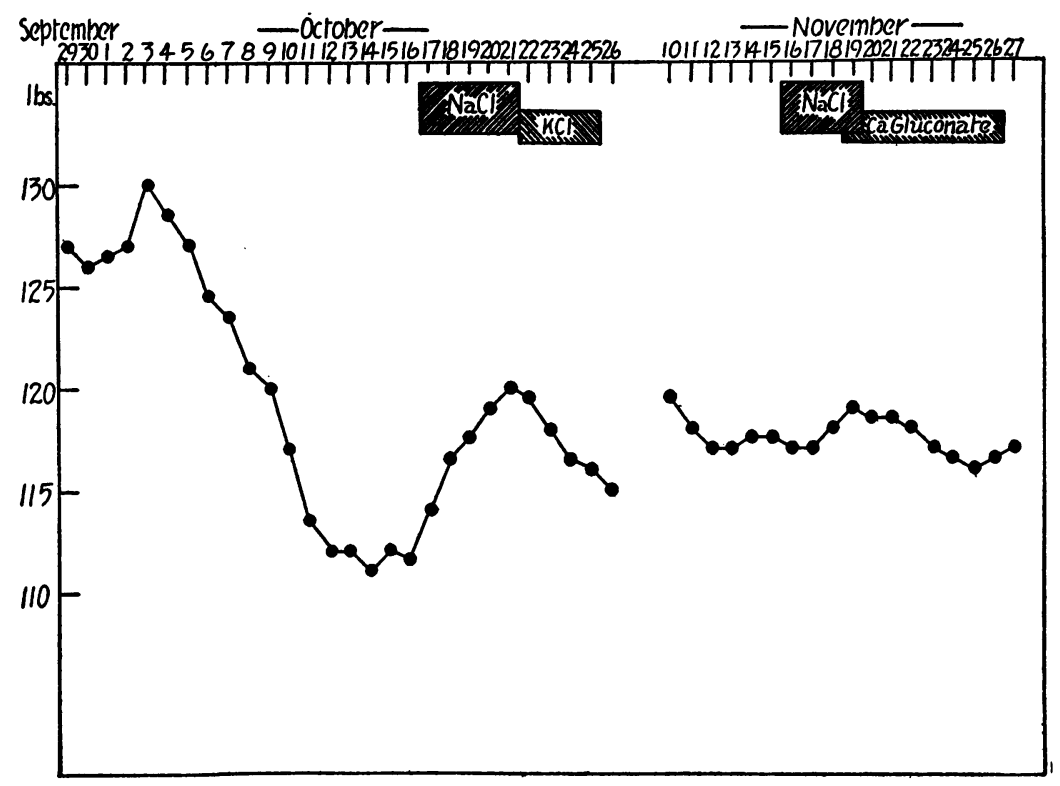

Fig. 1. Weight Curve in Patient with Nephrosis (Case I)

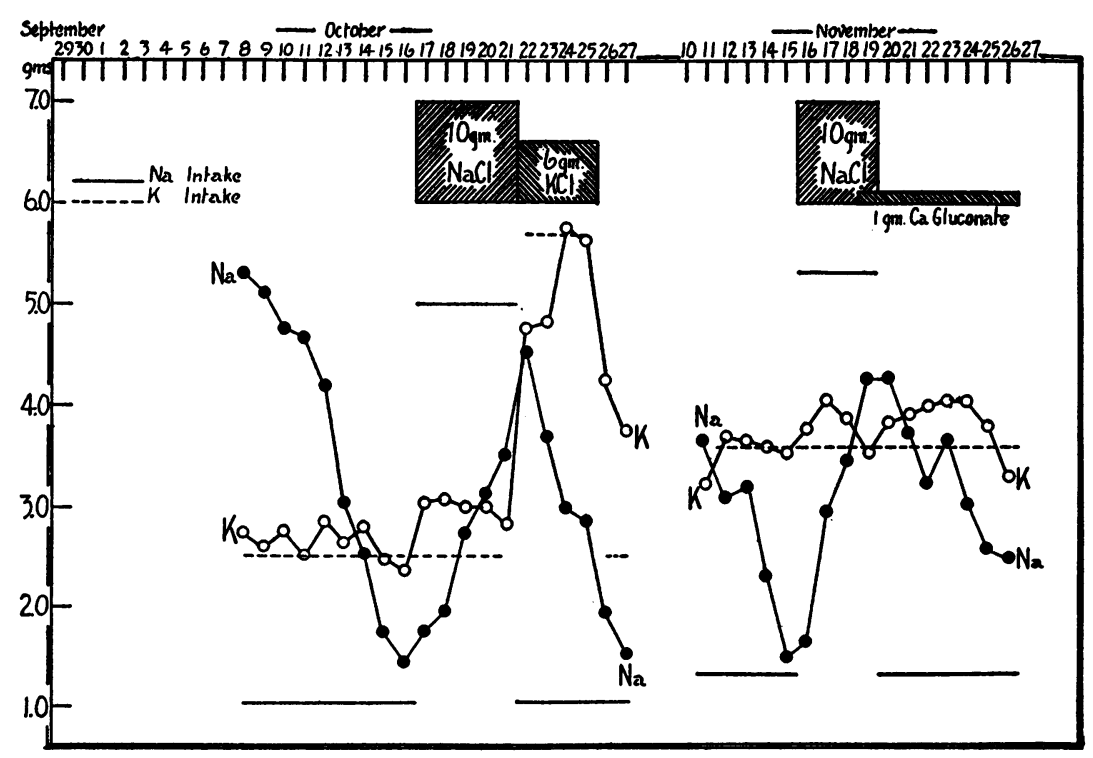

Fig. 2. Excretion of Sodium and Potassium by Patient with Nephrosis (CASe I) 
during the second period, even though he was getting 2050 calories. When taken off the quantitative restrictions, he gained weight at the rate of half a pound a day for several weeks without any indication of edema. These findings are summarized in Figure 1.

Table I gives the urinary data obtained in the various phases of the fluid balance. The general features of these data are the practically constant excretion of nitrogen, creatinine, calcium and magnesium throughout, no matter whether diuresis or production of edema was taking place. The proteinuria remained nearly constant, but did seem to show a tendency to diminution toward the end of the experiment. Urinary calcium excretion was very low, and was not appreciably altered by intravenous injection of calcium gluconate.

The features which are of most interest for the purpose of this investigation are the relation of sodium, chloride, potassium, and water to each other. Figure 2 presents in graphic form the excretion of sodium and potassium and their relation to intake. These data can be more clearly understood if they are charted as balances and compared with that of water (Fig. 3). In a similar way, chloride and water balances ${ }^{3}$ are charted in Figure 4. It can be seen that both sodium and chloride balances ran parallel to that of water, both in the negative balance of diuresis and the positive one of edema formation. It can also be seen that the excretion or retention of a certain quantity of water seemed to be associated with the excretion or retention of a definite quantity of sodium and chloride, and tended to approach the proportion of sodium and chloride found in the plasma ( 3.3 grams $\mathrm{Na}$ and 3.5 grams $\mathrm{Cl}$ per $1000 \mathrm{cc}$.). Potassium, on the other hand, tended to remain in balance throughout. Its curve was entirely independent of that of water. There was seen, however, a small but definite negative balance of potassium during sodium and water retention, which was apparently compensated by a retention of potassium during the period following, when that element was supplied in abundance. A small negative balance of potassium also occurred during the period of diuresis in which calcium gluconate was given.

During the period in which $\mathrm{NaCl}$ was administered, at first almost all the sodium was retained, but with each successive day less was retained, until on the last day of its administration, in the second period, the patient excreted practically all the ingested sodium. On this day calcium gluconate injections had been started, and it was at first believed that the good excre-

8 It must be understood that the water balance charted merely represents the difference between the fluid intake and urinary excretion. It does not include the various other items in the water balance, such as water of solid foods, water of oxidation, fecal water and insensible water loss. But these items were believed to be practically constant throughout the experiment. Their inclusion would, if this is so, only raise or lower the water curves throughout, but would not alter the shape of the curves. 


\begin{tabular}{|c|c|c|c|}
\hline \multirow{15}{*}{ 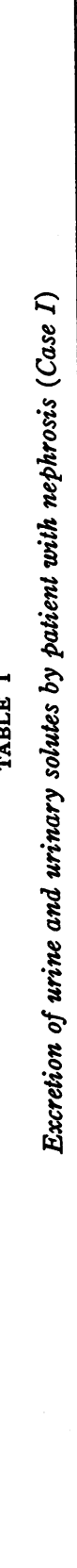 } & 㟧 & & 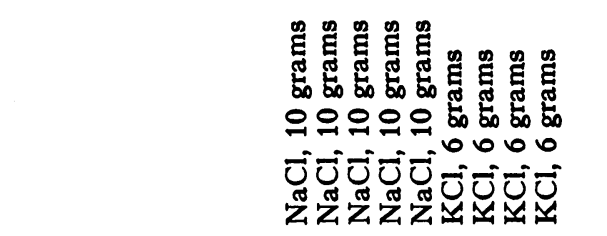 \\
\hline & 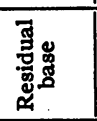 & & 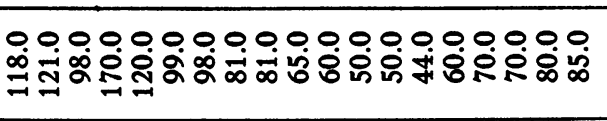 \\
\hline & 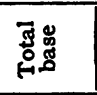 & & 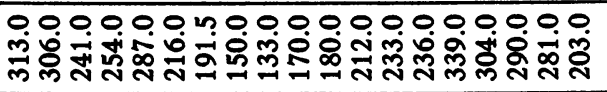 \\
\hline & 恶 & 告 & 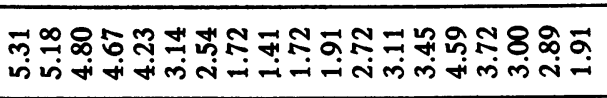 \\
\hline & 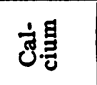 & 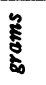 & 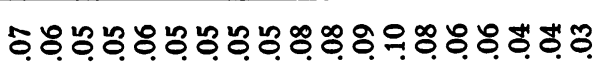 \\
\hline & 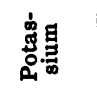 & है & 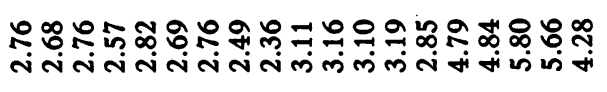 \\
\hline & 嵌慁 & $\frac{5}{6}$ & 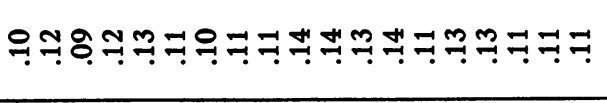 \\
\hline & 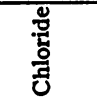 & $\frac{2}{5}$ & 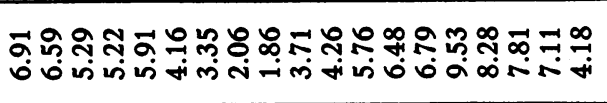 \\
\hline & 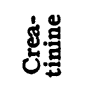 & 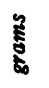 & 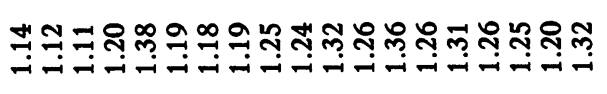 \\
\hline & 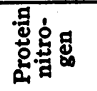 & 产 & 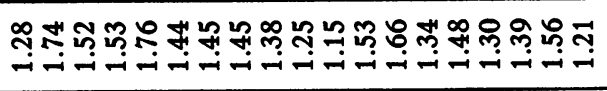 \\
\hline & 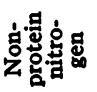 & & 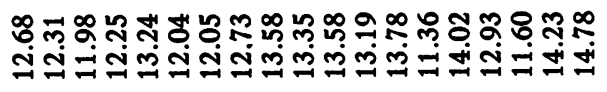 \\
\hline & 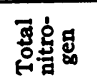 & & 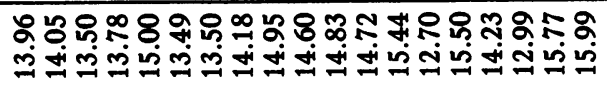 \\
\hline & 营言 & & 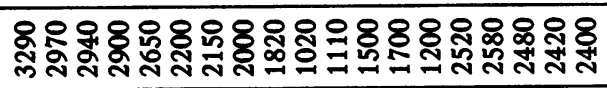 \\
\hline & 急苛 & & 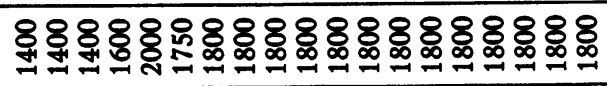 \\
\hline & مَّ & & \ูำ \\
\hline
\end{tabular}




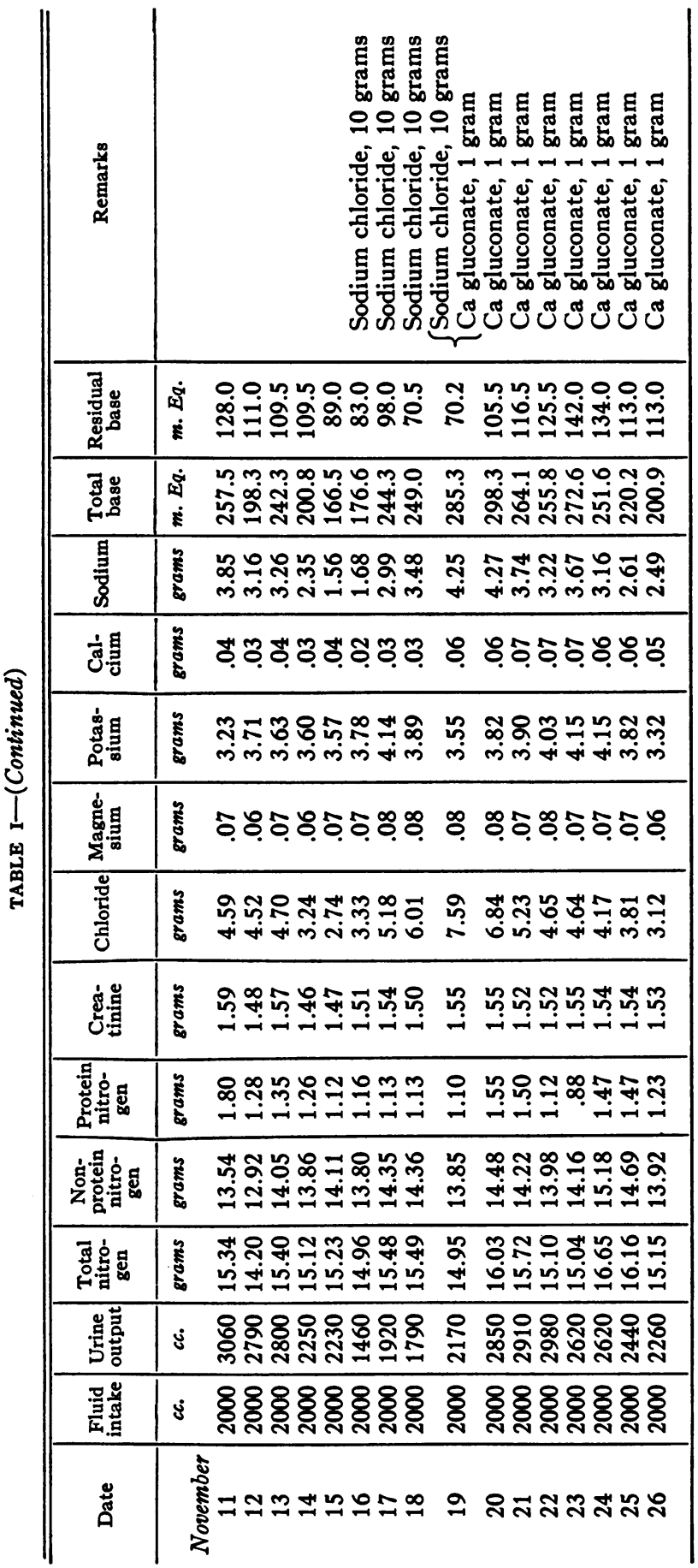




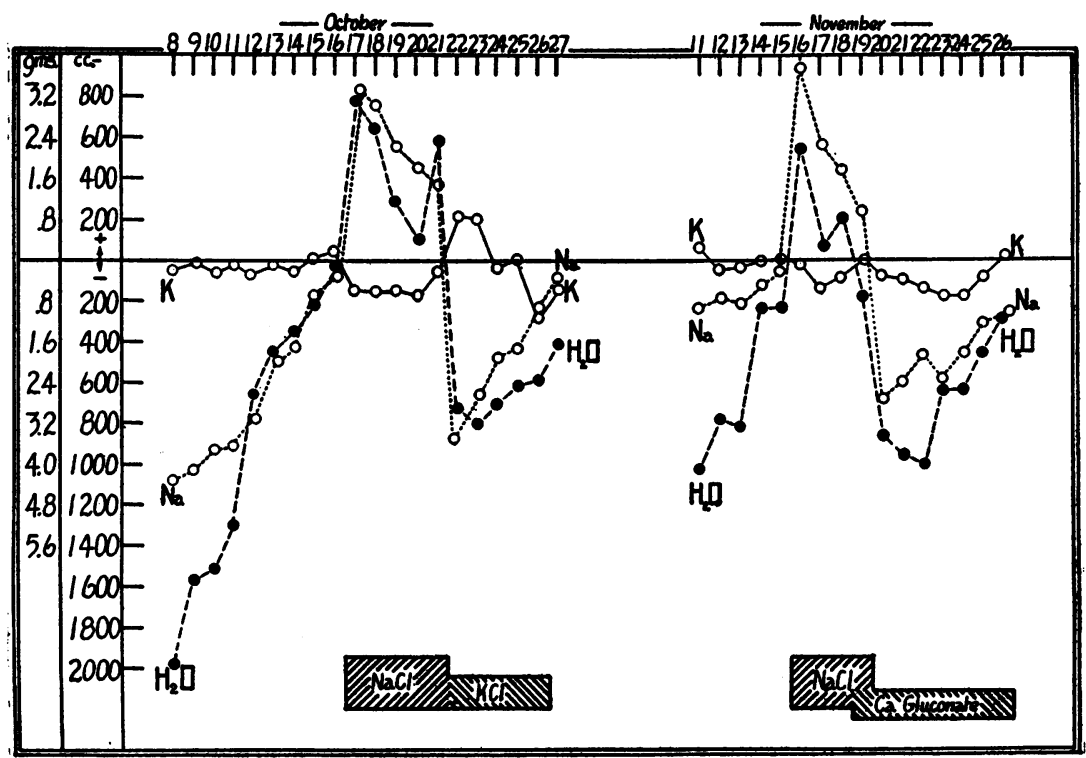

Fig. 3. Water, Sodium, and Potassium Balances in Patient with Nephrosis (CASE I)

Ordinates represent not actual excretion but difference between intake and output.

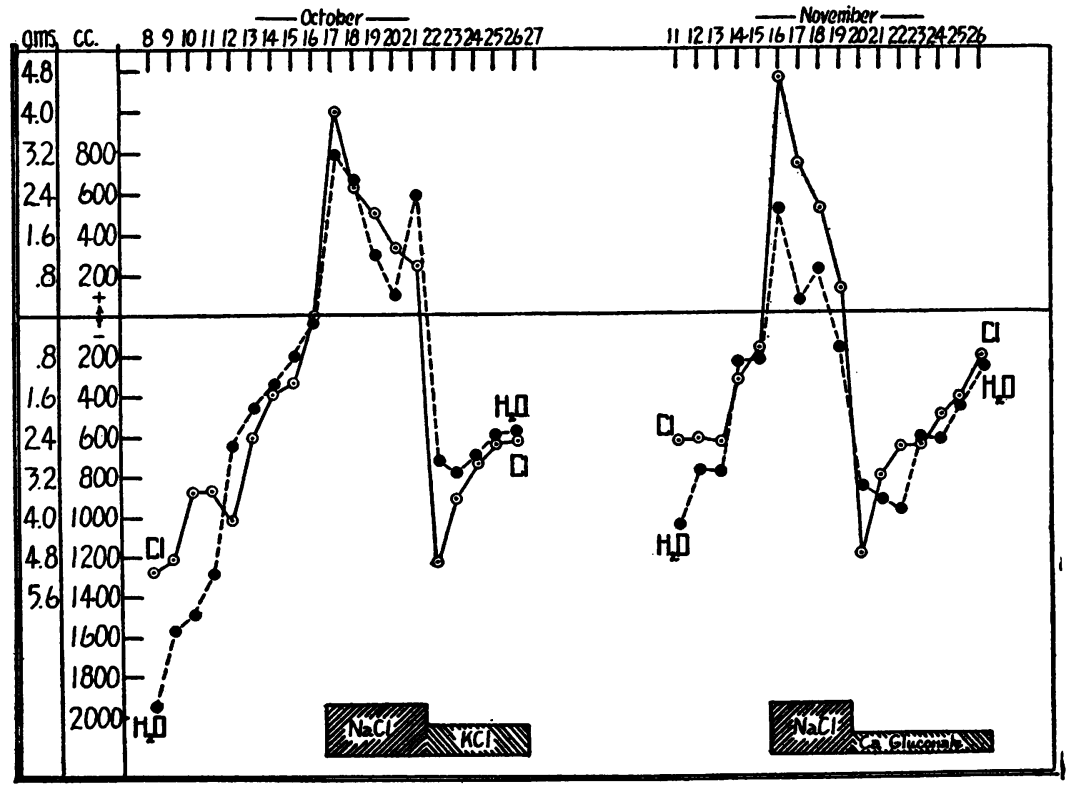

Fig. 4. Water and Chloride Balance in Patient with Nephrosis (CASE I)

Ordinates represent difference between intake and output. 
tion was produced by the effects of this injection. However, the subsequent studies of further injections both in this patient and several others have made us feel that calcium gluconate in the quantities which we have used is of very little influence in nephrotic edema. The balance between intake and excretion on the aforementioned day was apparently part of the picture of continued increase in excretion as more and more sodium chloride was given. Had we recognized the phenomenon at the time, we should have dared to continue to give $\mathrm{NaCl}$ and should have hoped to see a new balance formed in which the patient maintained his moderate edema and excreted all ingested sodium chloride from that time on.

During diuresis the excretion of extra sodium exceeded that of chloride in terms of milliequivalents of base and acid. During edema production, more sodium was retained than chloride. This phenomenon is more clearly recognized if one examines the residual base in urine (Fig. 5), - that is, the

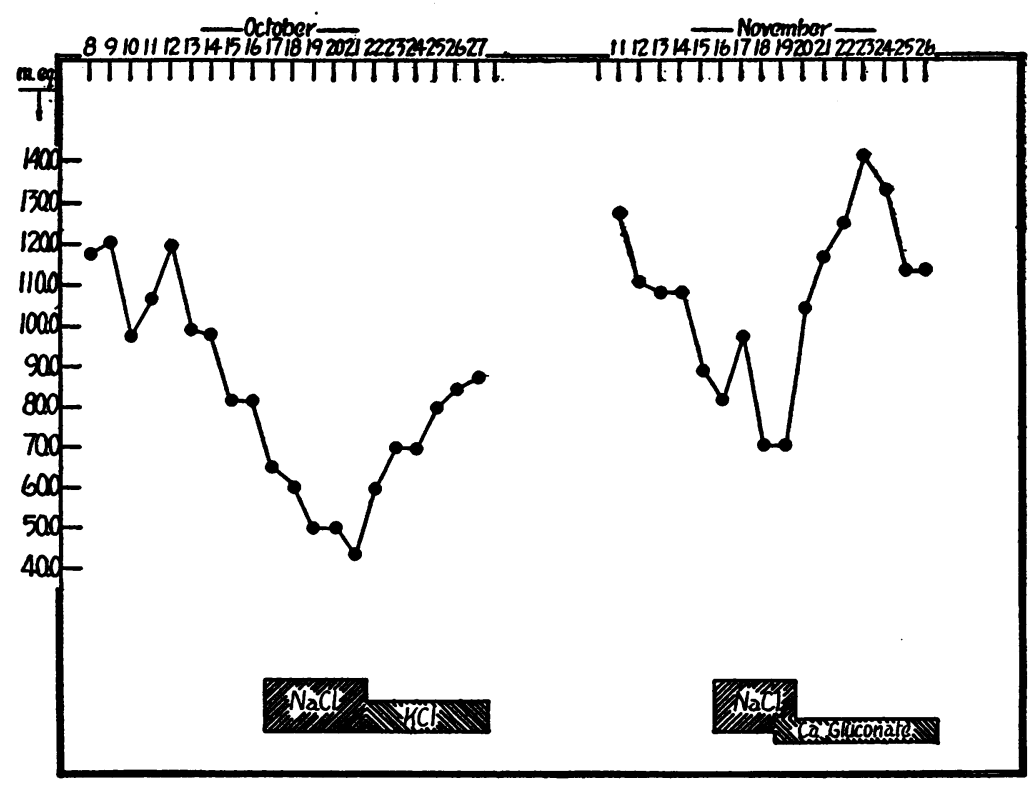

Fig. 5. Residual Base Excretion by Patient with Nephrosis (Case I)

Ordinates represent urinary total base minus urinary chloride as milliequivalents.

total fixed base minus the chloride, which represents the bases available for neutralization of other excreted acids. The residual base was high at the height of diuresis and lowest at the height of edema production. The curve is complicated by the extraneous factors of ingested $\mathrm{KCl}$ and calcium gluconate, but the general features are recognizable.

Table II presents the blood chemical data in Case I. All the classical features of the nephrotic picture were present. Urea, $\mathrm{CO}_{2}$-combining 


\begin{tabular}{|c|c|c|c|c|c|}
\hline & 离 & 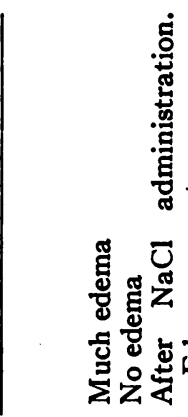 & 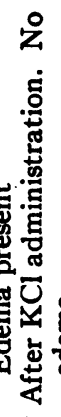 & 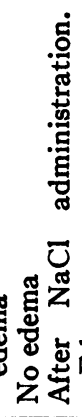 & 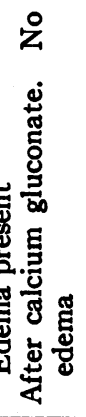 \\
\hline & 总 & 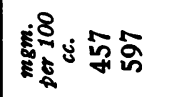 & & 홍웡 & 융 \\
\hline שั. & 悹: & E్ & $\cong$ & 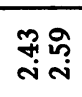 & $\stackrel{F}{=}$ \\
\hline 5 & 谒 & | & 管 & "ִ & ì \\
\hline & 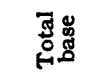 & घี่ & & ผิํํㅇ & 8 \\
\hline 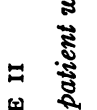 & 紊 & 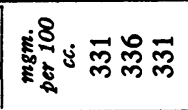 & & 品些 & 祢 \\
\hline$\frac{5}{5}$ & 䋩 & 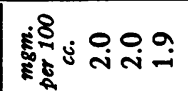 & & $\stackrel{\infty}{\longrightarrow}$ & $\stackrel{\circ}{i}$ \\
\hline $\begin{array}{l}5 \\
5 \\
5\end{array}$ & 暨 & |ن نُ & & $\stackrel{0}{\infty} \stackrel{-\pi}{-1}$ & ณ̊ำ \\
\hline క్ँ & ชં. & : & & 㑒 & $\underset{\infty}{\sim}$ \\
\hline हुँ & 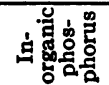 & हู่ & $\stackrel{m}{m}$ & में & \\
\hline & 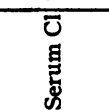 & : & & 응 & $\frac{\pi}{0}$ \\
\hline & 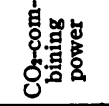 & 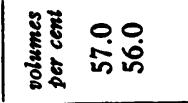 & $\stackrel{9}{\circ}$ & ชิ & $\ddot{\ddot{\theta}}$ \\
\hline & $\$$ & بَّ & 유. & $\stackrel{\sharp}{\dddot{m}}$ & \\
\hline & ณँ & 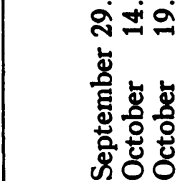 & 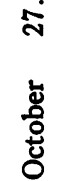 & 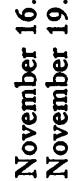 & 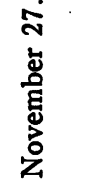 \\
\hline
\end{tabular}


power, phosphorus, and potassium were all normal. Total protein was low, with a reversal of the albumin-globulin ratio. Calcium was correspondingly low, and so was magnesium. Cholesterol was high. Total base, sodium and chloride were at a high normal level, and even higher at the time of administration of sodium chloride. However, throughout the whole study, there were no greatly significant changes in the concentration of these latter constituents, in spite of the marked variation in the daily excretion. Osmotically these are the important items in the plasma, and the osmotic pressure therefore remained very nearly the same no matter what quantity of fluid was present in the body. It should also be noted that edema subsided or formed without any marked changes in the protein concentration, which always remained far below the 5 gram critical level that Van Slyke found to be the level at which edema tends to appear.

Case II. The second patient studied showed a similar but more severe picture of nephrotic edema with the added complication of definite evidence of vascular and glomerular damage, with increased blood pressure and

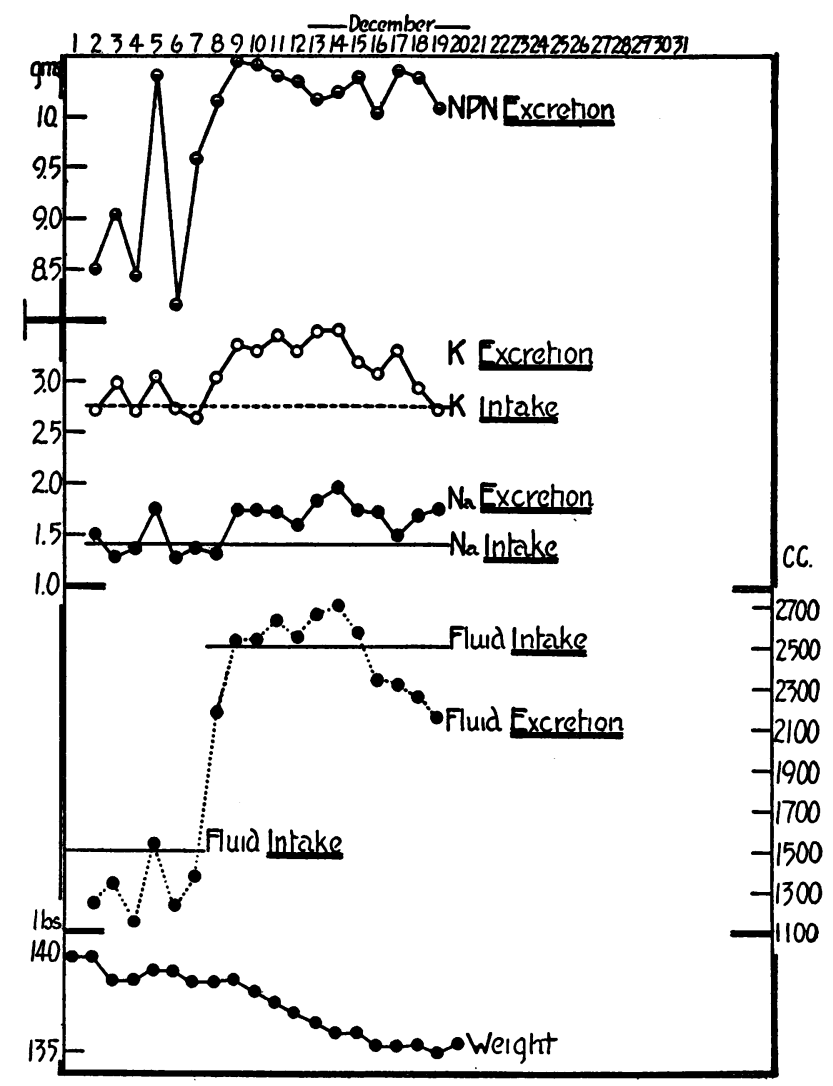

Fig. 6. Urinary Excretion in Relation to Intake in Patient with Chronic Nephritis with Edema (CASe II) 
diminished kidney function. He was placed on a diet similar to that given the first patient and furnishing 1770 calories. He failed, however, to show the same prompt diuretic response seen in the former subject. After six days, the fluid intake was increased from $1500 \mathrm{cc}$. to $2500 \mathrm{cc}$., everything else being kept constant. Moderate diuresis immediately began, with an attending negative balance of water, sodium, potassium, chloride, and nitrogen. (See Fig. 6.) However, this diuresis could not be maintained, in spite of the daily injection of calcium gluconate, and the patient returned to a new state of balance, retaining about 18 pounds of edema fluid. When the intake was further increased to $3000 \mathrm{cc}$., instead of a loss of fluid from the body, there was a rapid gain of five pounds in four days with a slight diminution in the output of sodium and chloride. With the return of the fluid intake to $2500 \mathrm{cc}$., a new balance was set up with a constancy of weight. At this stage, 4 grams of $\mathrm{NH}_{4} \mathrm{Cl}$ were given daily until moderate acidosis was produced. There was no diuresis; the added chloride was almost entirely retained and there was a slight gain in edema fluid. (See Fig. 7.) At this point, the patient developed a streptococcus pneumonia,

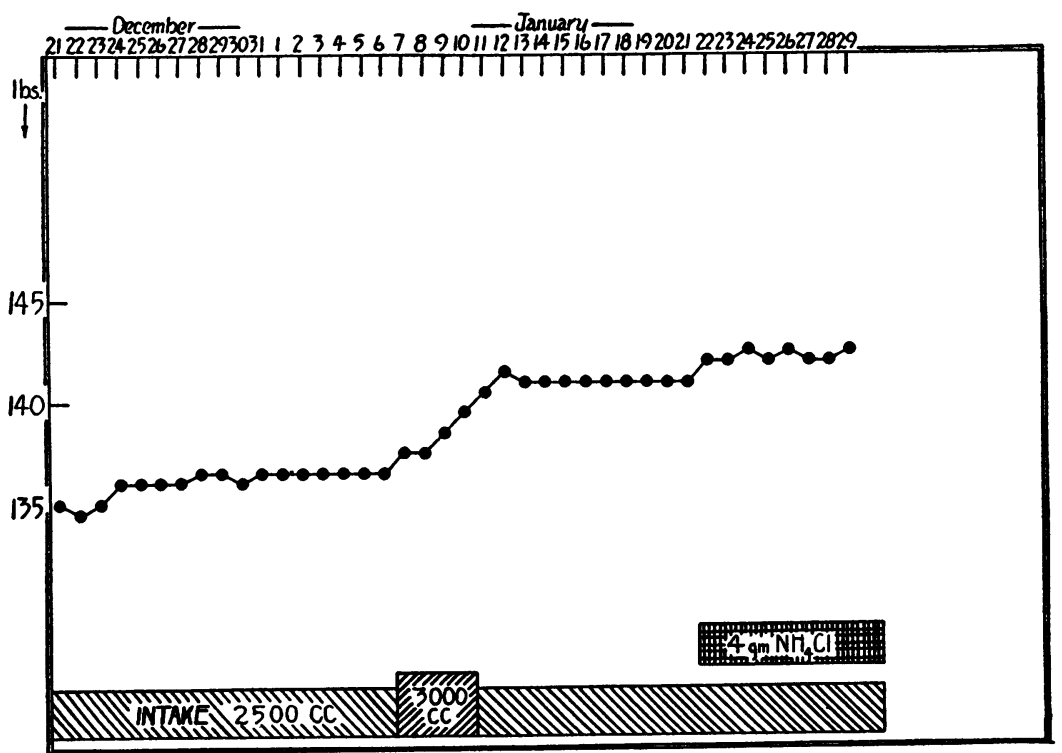

Fig. 7. Weight Curve of Patient with Chronic Nephritis with Edema (CASE II)

Continuous with weight curve in Figure 6.

and his condition was so poor that no further studies could be made. This circumstance was all the more unfortunate in that during this severe illness, when the diet had to be changed to milk, orange juice, glucose, vegetable stews and potassium citrate, there was a rapid diuresis, which, with the excessive sweating during the febrile period, produced a complete loss of 


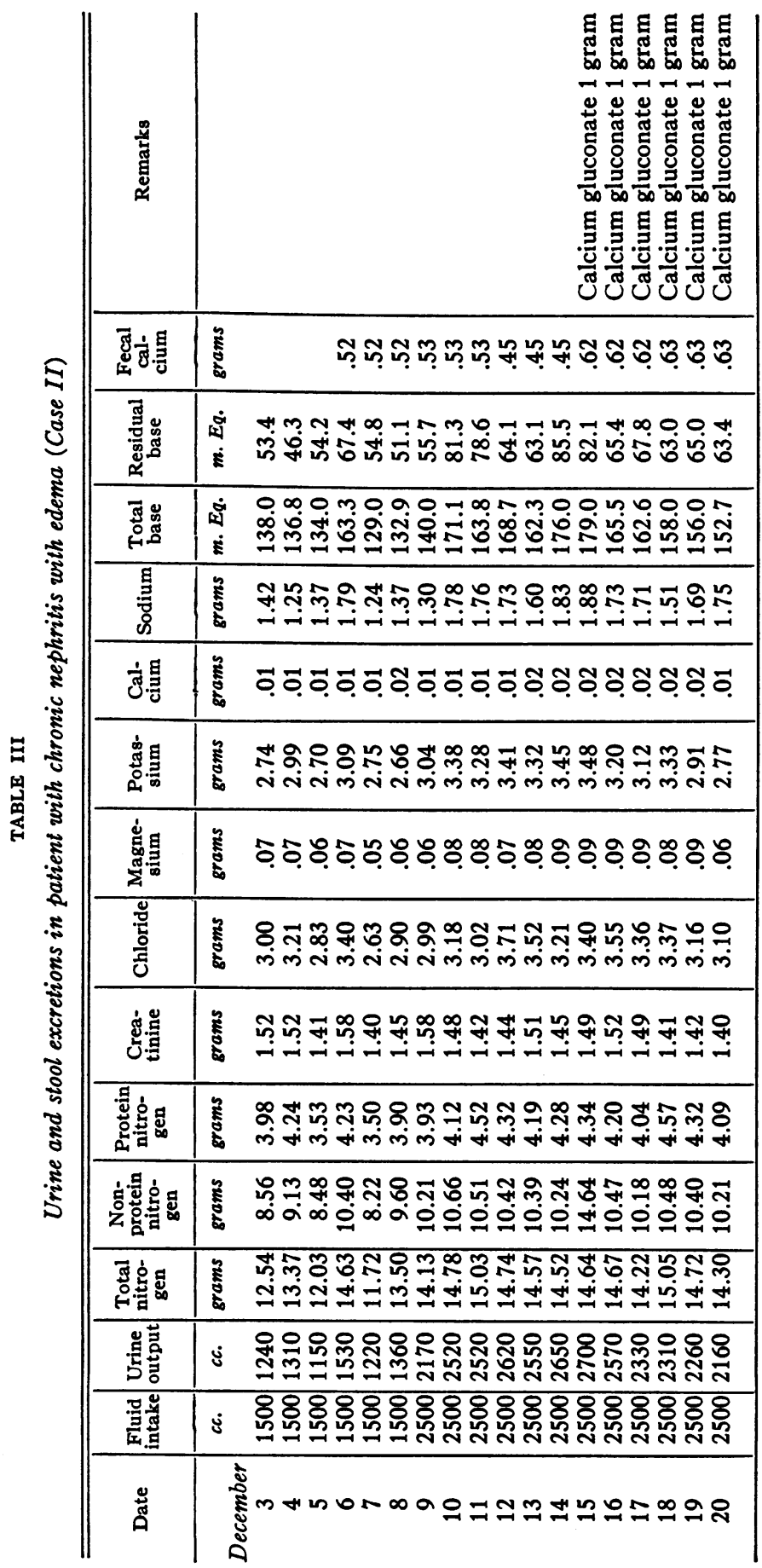


edema. After the recovery from pneumonia, it was easy to keep the patient edema free on the original diet.

The urinary and fecal excretions for the first 19 days are given in Table III. Total calcium balance was studied for a period of 15 days. It was found that $100 \mathrm{mgm}$. of calcium injected daily as calcium gluconate was totally recovered in the feces. The urinary calcium remained exceedingly low throughout the entire study. The later urinary studies have been omitted here because they show no essential variations in the output of the inorganic constituents, except for a slight diminution in the excretion of sodium and chloride during the period of increasing edema when the fluid intake had been raised to $3000 \mathrm{cc}$. and a slight increase in the excretion of chloride when $\mathrm{NH}_{4} \mathrm{Cl}$ was administered.

In Table IV, the blood chemical data on Case II illustrate the usual finding in chronic glomerulonephritis in the stage of nephrotic edema with nitrogenous retention. It is of interest that the nitrogenous retention remained practically unchanged in spite of the high protein diet, quite as Keutmann and McCann (23) found in their cases. The data on the mineral contents of the serum were limited because of the technical difficulty in obtaining samples of the serum that did not gel. The limited analyses, however, show a high total base as well as a high chloride concentration.

Cases III and IV. Metabolic balance studies in Cases III and IV were unsatisfactory, as has been mentioned. This was unfortunate, because the patients were brothers, one of whom was recovering from a nephrosis and was now edema free, while the other had a severe, intractable edema that did not improve on any management. The brothers were studied " in parallel," both being on the same diet, with the proposed purpose of using one as a control for the other, thus to obviate the uneven results produced by the weather and the excessive losses of perspiration. However, the edematous brother could not be made to eat his diet no matter how much it was reduced. The results obtained, therefore, were not of the same type as those from the first two patients.

The convalescing patient remained edema free throughout the study. Even when given 10 grams of $\mathrm{NaCl}$ daily, he did not show any edema; instead he excreted a good proportion of the additional sodium and chloride in the urine (and probably the remainder in the perspiration). His serum protein totaled 5.1 grams per $100 \mathrm{cc}$. With a serum calcium of $8.9 \mathrm{mgm}$. per $100 \mathrm{cc}$., he showed a good urinary calcium excretion of about $150 \mathrm{mgm}$. per day. The serum total base concentration was 159 milliequivalents per liter.

The edematous brother kept gaining in weight even with a diet very low in salt. He held his own with an intake of $1000 \mathrm{cc}$. of fluid better than with $1500 \mathrm{cc}$. or $2500 \mathrm{cc}$. At no time was any significant diuresis produced during the study in spite of the administration of $\mathrm{KCl}, \mathrm{NH}_{4} \mathrm{Cl}$, calcium gluconate, parathyroid hormone, or potassium citrate, at various times. 


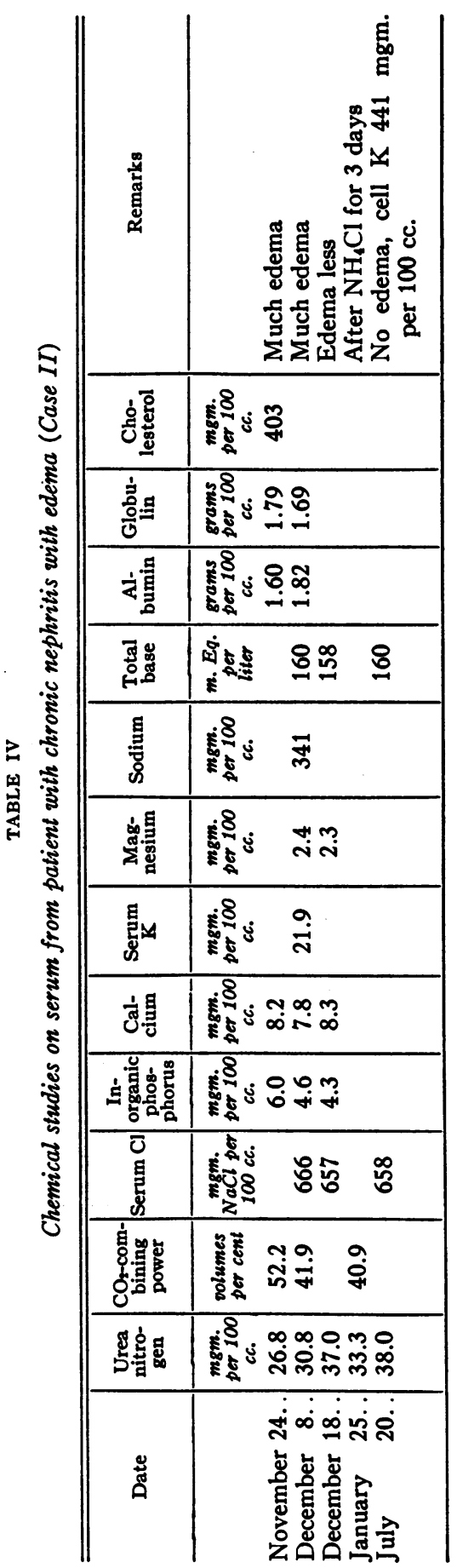


Salyrgan along with $\mathrm{NH}_{4} \mathrm{Cl}$ gave the greatest excretion but the results obtained were not encouraging enough to risk extended mercurialization and acidosis.

At the beginning of the study, the urine showed $800 \mathrm{mgm}$. of sodium. This excretion diminished rapidly until the urine showed no sodium at all. (In fact, since sodium was determined by difference, the actual sodium value obtained was at times negative.) This absence of urinary sodium occurred during a period in which the temperature remained in the neighborhood of $100^{\circ} \mathrm{F}$. The patient perspired excessively. At this stage, the blood serum showed normal chloride, low total base, low serum and red cell potassium. This blood picture, associated with little or no sodium and chloride in the urine, is the characteristic feature of dehydration. In other words, in spite of the presence of 70 pounds of edema fluid, a low water and salt intake combined with excessive perspiration produced exactly the same urinary and blood findings of dehydration that would be found in a normal person on the same management. This illustrates the futility of sweating as a therapeutic procedure for the relief of edema.

For the purpose of further studying the relationship of the concentration of the minerals in the blood to the excretion of sodium and water, the potassium partition of the blood was determined on three different occasions,- - first, when there was no longer any sodium excreted in the urine, secondly, during the period of administration of $\mathrm{KCl}$, when the urinary excretion did increase slightly and small amounts of sodium reappeared in the urine, and thirdly, when, after $\mathrm{NH}_{4} \mathrm{Cl}$ had failed to produce a diuresis and had caused a marked acidosis because of retention of chloride, potassium citrate had been administered to counteract the acidosis. The results are shown in Table V. The normal concentration obtained by Hoffman and Jacobs for the red cell potassium is $423 \mathrm{mgm}$. per $100 \mathrm{cc}$. of red cells. At the time of dehydration, the red cell potassium was low as was the serum total base and sodium. After the administration of $\mathrm{KCl}$, the red cell potassium rose to $462 \mathrm{mgm}$. per $100 \mathrm{cc}$. with a corresponding rise in the serum total base and sodium, and with a reappearance of sodium in the urine. In the last period, potassium citrate failed to produce any diuresis and sodium was absent in the urine. In this period, the added potassium was followed by increased potassium concentration only in the serum. The red cell potassium remained low, as did the serum total base and sodium. In their study of 112 persons, Hoffman and Jacobs found, in general, that the level of serum base ran parallel to the level of the red cell potassium. They also found that in each of three patients with nephrotic pictures, but without edema, the serum total base concentration was high.

\section{COMMENT}

From this group of apparently unrelated findings, some measure of synthesis can be achieved which might add to the understanding not only 


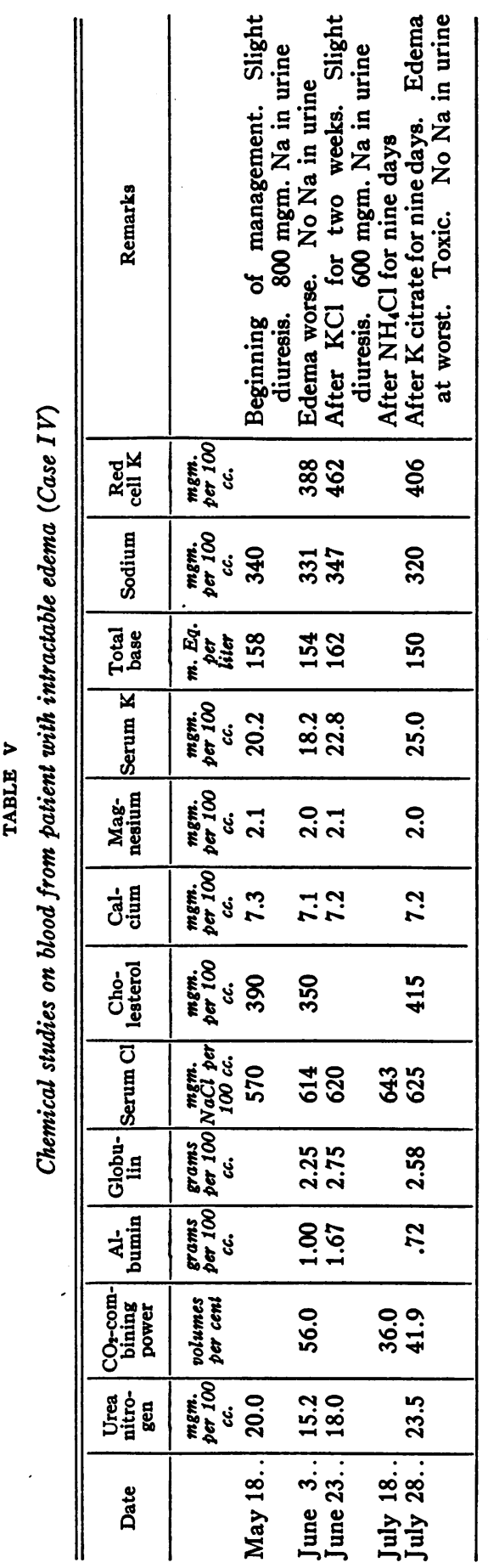


of the phenomenon of nephrotic edema but also of water and mineral metabolism in general. The study of our first patient shows that water, sodium, and chloride are retained or excreted in the process of edema formation or remission in the proportions found in the blood plasma, and that the plasma concentration itself varies comparatively little during these phases. These findings agree with those of Gamble et al. (24) in their study of water excretion in epileptic children managed by dehydration. This relationship can be more readily appreciated, if one recognizes, as Loeb et al. (2) have pointed out, that the amount of transudation of fluid across the capillary walls depends not only upon the degree of lowering of the serum oncotic pressure, but upon the quantity of water, sodium and chloride which must be distributed between plasma and the extracellular fluids in order to maintain the osmotic pressure of these fluids somewhere near normal.

It is apparent from our findings that the actual quantity of fluid retained in the extracellular spaces is also determined by the rate of excretion by the kidneys of water, sodium, and chloride. The factors which influence this rate include among others the degree of intactness of the cardiovascular system, the relative efficiency of the kidneys, and the concentration of sodium and chloride in the plasma. Since, in pure nephrosis, there is little or no evidence of impairment of the heart, blood vessels, or kidneys, it is the question of the concentration of sodium and chloride that must be considered. In Case I, the sodium and chloride concentrations were at a high normal level even when no edema was present, and higher than normal at the height of diuresis. High serum sodium was found in two other patients with the nephrotic picture but without edema. Moreover, the first patient demonstrated an increasing ability to excrete sodium, chloride, and water as more and more sodium chloride was ingested, until he reached a rate of excretion which was equal to that of intake, in spite of the low serum protein concentration and the large quantity of ingested $\mathrm{NaCl}$. Albright and Bauer (25) have called attention to a similar increased excretion of sodium and water on the ingestion of sodium bicarbonate.

In contrast to the first patient, the fourth had low serum sodium, even though he had an enormous amount of edema. In fact, his blood and urine picture, at the time of excessive perspiration, resembled that seen in dehydration, that is, low serum sodium, low red cell potassium, and little or no sodium or chloride in the urine. When $\mathrm{KCl}$ was given in large enough quantities to produce a rise in the cell potassium concentration, the serum total base and sodium also rose, and sodium now appeared in the urine. Apparently, then, there is a threshold concentration of sodium in nephrosis below which sodium is not excreted by the kidneys. This threshold seems to be close to the normal level of serum sodium, which, with the technique used here, corresponded to a total base concentration of about 156 milli- 
equivalents per liter. Albright and Bauer (25) and Loeb et al. (2) suggest the possibility of such a threshold for sodium excretion.

If this idea is correct, it is possible to offer an explanation for the difference between the response of two subjects with serum oncotic pressure lowered to the same extent. The patient whose serum sodium is normal or higher than normal will excrete an adequate amount of sodium (and with it its quota of water and chloride), whereas the patient whose serum sodium is lower than normal will excrete little or no sodium. This explanation might serve, too, to account for the failure of $\mathrm{NH}_{4} \mathrm{Cl}$ to produce diuresis in some cases. The diuretic action of acid-producing salts, as has been shown by the work of Gamble (26), Linder (27) and others, is directly proportional to the amount of sodium excreted to neutralize the excess of excreted acid. In a patient like that of Case IV, whose serum total base was low, no sodium would be available for neutralization, so that only that amount of chloride would be excreted which could be neutralized by other bases and ammonium. No diuresis would, therefore, occur. In fact, the retention of chloride, requiring, as it does, a redistribution of water and sodium of the extracellular fluids, might even increase the amount of edema fluid. This phenomenon seemed to occur in Cases II and IV.

In Case II, the factors of circulation and kidney function were probably important. The patient's urea clearance ranged from 44 per cent to 22 per cent of normal. He could not concentrate his urine to a maximum. With $1500 \mathrm{cc}$. fluid intake, a low sodium diet produced no diuresis, even though the serum sodium was high. A moderate increase of water intake apparently improved his excretory power sufficiently to produce a negative balance for sodium and chloride, which carried along their quota of extra water, so that a temporary diuresis occurred. In fact, the excretion of potassium and nitrogen also increased. However, when the water intake was further increased, the burden of excretion of water itself apparently now became marked enough to produce a lag in excretion, with a resulting retention of water, sodium, and chloride. Why spontaneous diuresis occurred at the time of fever,-which phenomenon has been observed and reported on by others (2),-is not known. That it might be concerned with the resorptive function of the tubular cells is suggested by the fact that at the time of the diuresis there was an enormous increase in casts, epithelial and white cells, and that after the edema had completely subsided and the patient had recovered from the illness, the urea clearance was lower than at the beginning of the study.

The fact that edema fluid, like blood plasma, has approximately 143 milliequivalents of sodium and only about 105 milliequivalents of chloride leads during the formation or removal of edema to a difference between the balance of sodium and chloride not found in normal individuals after ingestion of $\mathrm{NaCl}$. If $\mathrm{NaCl}$ is ingested by a normal person, it is excreted as such. But if the ingestion is associated with the formation of edema, 
about 143 milliequivalents of sodium are retained for every 105 of chloride, so that the urine contains extra chloride and a decreased amount of residual base. The reverse is true during remission of edema. Edema fluid thus acts as a large reservoir of alkali. This neutralizing mechanism was illustrated in Case IV when 8 grams of $\mathrm{NH}_{4} \mathrm{Cl}$ daily ingested for nine days produced an alteration of the $\mathrm{CO}_{2}$-combining power only from 56 to 36 volumes per cent, in spite of the marked retention of chloride. Ascitic fluid obtained by paracentesis abdominis on the fourth day of the $\mathrm{NH}_{4} \mathrm{Cl}$ administration gave the following analysis: Total base, 152 m.eq. per liter; $\mathrm{CO}_{2}$-combining power, 49 volumes per cent; $\mathrm{Cl}, 684 \mathrm{mgm}$. $\mathrm{NaCl}$ per 100 cc.; K, $15.0 \mathrm{mgm}$. per $100 \mathrm{cc}$; protein, 0.19 gram per $100 \mathrm{cc}$. These values, with the exception of that of protein, are of the order of those found in the blood and give an idea of the neutralization of retained chloride.

It has been mentioned that calcium gluconate was found to be of little value in promoting diuresis in these patients. However, it must be admitted that only $10 \mathrm{cc}$. of 10 per cent calcium gluconate were given daily, which quantity represents only $100 \mathrm{mgm}$. of calcium. In the one patient studied for calcium balance, the $100 \mathrm{mgm}$. were completely recovered in the feces, which can mean only that the blood level of calcium was never continuously elevated above the threshold value of 8.5 to $9 \mathrm{mgm}$. per $100 \mathrm{cc}$. found by Albright and Ellsworth (28). Even the addition of 20 units of parathyroid hormone caused no appreciable increase in the extremely low urinary calcium of the fourth patient. The beneficial results reported by O'Donnell and Levin (29) in nephrotic children may have been produced by a more effective rise in the serum calcium concentration.

\section{SUMMARY AND CONCLUSIONS}

Four patients with nephrotic edema were studied in careful metabolic balance experiments for the relationship of the mineral metabolism to edema. The essential findings were:

1. Both the sodium and chloride balance curves ran parallel to the curve of water balance, both during edema formation and edema remission.

2. The amount of sodium and chloride associated with the excretion or retention of water approached the proportions of these elements found in blood plasma.

3. The concentrations of sodium and chloride in the plasma varied only slightly in the various phases of edema, but were higher than normal at the time when there was adequate excretion of sodium and chloride.

4. Potassium was practically in balance at all times, except for a slight negative balance during the time of production of edema, with a compensatory retention during diuresis.

5. In the patient with a complicating impairment of renal function, an 
increase of fluid intake from $1500 \mathrm{cc}$. to $2500 \mathrm{cc}$. caused a temporary diuresis, but a further increase to $3000 \mathrm{cc}$. produced an even greater edema.

6. Spontaneous diuresis occurred during an acute infection.

7. Excessive perspiration produced in the patient with intractable edema a blood and urine picture of dehydration, with low serum total base concentration, low red cell potassium concentration, and the disappearance of sodium from the urine.

8. Ingestion of $\mathrm{KCl}$ raised the level of both the red cell potassium concentration and that of the serum total base, and caused sodium to reappear in the urine.

9. Ammonium chloride ingestion caused retention of chloride, when sodium excretion was inadequate because of the low level of total base in the serum; and this retention of chloride further increased the edema and produced acidosis.

10. Edema fluid acts as a reservoir of alkali.

11. Calcium gluconate, injected intravenously in daily doses of 100 $\mathrm{mgm}$. of calcium, had no influence upon the edema.

These findings suggest the following conclusions. Ingestion of water, sodium or chloride produces a transudation of these substances across the capillary walls to keep the osmotic relations of the plasma and extracellular fluids somewhere near normal, until the excretion by the kidneys restores the normal body content. A low serum protein concentration produces a tendency for accumulation of extracellular fluid because of the lag in the return of fluid into the blood stream. The extent of this accumulation is determined, among other factors, by the speed with which the kidneys carry on the excretion of water, sodium, and chloride. Adequate excretion of sodium (and therefore of its quota of water and chloride) in nephrosis is apparently possible only when the serum sodium concentration is at a normal or higher than normal level. The serum sodium concentration seems to be related to that of red cell potassium, and factors which raise the latter may raise the concentration of serum sodium and thereby increase the urinary excretion of sodium.

\section{APPENDIX}

\section{CASE HISTORIES}

Case I. W. S., a male white patient of 27 , was admitted to Presbyterian Hospital in September, 1931 and discharged in December, 1931 with a diagnosis of nephrosis.

History of present illness. Nine months before admission, the patient began to notice swelling of the ankles and a feeling of weakness and ease of tiring. There had been no previous history of infection, with the exception of an abscessed tooth which had been removed one week previous to the onset of the edema. A week later, the patient became confined to bed with a sore throat and coryza, which lasted for two weeks. The edema progressed, became generalized, and involved the body cavities. The patient complained at times of dyspnea and 
of nausea and vomiting. There was no fever, no blood in the urine, and no elevation of blood pressure. The patient was admitted into Cook County Hospital and treated with a high protein diet, thyroid and salyrgan. He lost some edema, but when transferred to Presbyterian Hospital had had the same weight for the previous month. His best weight before his illness had been 135 pounds. At the beginning of our study, he weighed 130 pounds, with a moderately severe edema.

Physical examination. He had generalized subcutaneous edema, with moderate ascites, slight hydrothorax and pulmonary edema. He appeared undernourished, in spite of the edema. His teeth were in poor repair, and his tonsils, though small, appeared chronically infected.

Laboratory findings. The blood showed: R.B.C., 4,900,000; W.B.C., 9,100; Hemoglobin (Newcomer), 92 per cent. His urine contained about 9 grams of protein in 24 hours; there were many hyaline casts, but no red cells. The patient could concentrate his urine to 1.026. His phenolsulphonphthalein excretion was 55 per cent in two hours on one occasion, 83 per cent on another. His urea clearance was 88 and 97 per cent of normal on two occasions. Cultures from the urine were negative. The Wassermann and Kahn tests were negative. The blood pressure varied from 105 to 122 systolic; from 70 to 78 diastolic. His basal metabolic rate was -16 per cent, but when edema disappeared it became -7 per cent with essentially the same consumption of oxygen. His blood chemistry showed the findings of pure nephrosis.

Progress. Since the completion of the study, the patient has continued to improve clinically and has regained his former weight without reappearance of edema, despite his continued proteinuria.

Case II. C. H., a white male of 35, was admitted to Presbyterian Hospital in October, 1931 and discharged in March, 1932, with a diagnosis of chronic infectious nephritis with edema.

History of present illness. One year before admission to the hospital, the patient noticed a swelling of the ankles without any other accompanying symptoms. This edema gradually progressed to involve the entire body. He consulted many physicians and was treated by many different regimes. He remained with slight edema on a salt poor diet. Several months before admission, he was told to eat plenty of meat, and was given $\mathrm{KCl}$. He unwittingly ate meat that had been prepared by salting and gained 20 pounds of edema fluid in two weeks, in spite of the ingestion of $\mathrm{KCl}$. He complained of fulness in the abdomen for two hours after eating. He felt weak and had pains in the calves of his legs in walking. His best weight had been 170 pounds before his illness. He weighed 140 pounds at the beginning of this study with moderately severe edema. His appetite was poor. There were no previous illnesses, except scarlet fever in childhood, and a recurrent tonsillitis. The tonsils were removed before admission to the hospital. The family history was negative except that his mother had died of heart trouble at 50 .

Physical examination. The patient was an undernourished pallid person with subcutaneous edema involving chiefly the lower portion of the body. There was moderate ascites and a slight hydrothorax. The heart was enlarged both to the right and left. The liver was palpable, but not the spleen or kidneys. The teeth were in good repair, and the tonsillar beds were clean.

Laboratory findings. The blood showed: R.B.C., 3,580,000; W.B.C., 7,700; Hemoglobin, 56 per cent. His urine at times was syrupy with protein. There were numerous hyaline and granular casts, and at times red cells. The patient concentrated only to 1.020 (protein-free filtrate of urine). His phenol- 
sulphonphthalein excretion was 30,13 , and 20 per cent in two hours on three different occasions. His urea clearance was 44 per cent of normal at the beginning of the study and 22 per cent after an attack of bronchopneumonia in January, 1932. He showed at all times a slight nitrogenous retention, but no indican in the blood. His blood pressure varied, but frequently rose as high as 140 systolic and 105 diastolic. His basal metabolic rate was normal.

Progress. The edema diminished somewhat on $2500 \mathrm{cc}$. fluid intake, but increased on $3000 \mathrm{cc}$. Ammonium chloride produced more edema and an acidosis. It was at the time of this acidosis that a streptococcus bronchopneumonia developed, during which a complete remission of edema took place. After recovery from the pneumonia, he remained edema free on the original diet, but was found to have an intermittent glycosuria of 10 to 20 grams of glucose a day. The fasting blood sugar was, however, always normal, and at times even subnormal. No attempt was therefore made to lower the carbohydrate intake. He has continued to excrete about 25 grams of protein daily. In August, 1932, the blood proteins had increased slightly (albumin 1.58 gram per cent, globulin 2.95 grams per cent).

Case III. John C., aged 28, a white male, a railroad fireman, was admitted to the Illinois Central Hospital in April, 1932 and discharged in November, 1932 with the diagnosis of nephrosis.

History of present illness. The patient developed edema in December, 1930, and two weeks later was admitted to a hospital in Iowa with anasarca. He gave no previous history of infection, and no other symptoms. Paracentesis abdominis was done seven times. In June, 1931, the patient was sent home for two months, edema-free. He returned to the hospital in August, 1931, with recurrent edema, and was "tapped" again in October, 1931. In December, 1931, he became edema-free after having been placed on a high protein diet, and has had no edema since. He was admitted to the Illinois Central Hospital chiefly for study, because his brother (Case IV) was brought there with intractable edema.

Physical examination. The findings were essentially negative except for a slight undernourishment.

Laboratory findings. The blood picture was normal. The urine showed 3 to $\mathbf{5}$ grams of protein daily and a few casts. Red cells were found on several occasions. The blood pressure was 125 systolic and 80 diastolic. The basal metabolic rate was normal. The urea clearance test, the phenolsulphonphthalein excretion, and the concentration tests all showed normal renal function. The blood chemistry showed: urea nitrogen, $17 \mathrm{mgm}$. per $100 \mathrm{cc}$; glucose, $105 \mathrm{mgm}$. per $100 \mathrm{cc}$; $\mathrm{CO}_{2}$-combining power, 62 volumes per cent; albumin, 2.5 grams per $100 \mathrm{cc}$; globulin, 2.1 grams per $100 \mathrm{cc}$; cholesterol, $240 \mathrm{mgm}$. per $100 \mathrm{cc}$; calcium, $8.9 \mathrm{mgm}$. per $100 \mathrm{cc}$; s serum chloride, $630 \mathrm{mgm}$. $\mathrm{NaCl}$ per $100 \mathrm{cc}$; ; serum total base, 159 m.eq. per liter; red cell potassium, $407 \mathrm{mgm}$. per $100 \mathrm{cc}$.; indican, none.

Progress. The patient has remained edema-free and in fairly good health. A diet including 10 grams of $\mathrm{NaCl}$ given for five days did not produce any edema.

Case IV. Joe C., brother to John C. (Case III), a male white of 26, a railroad fireman, was admitted to Illinois Central Hospital in April, 1932. In November, 1932, he was still a patient there.

History of present illness. The patient first noticed a painless swelling of the ankles in November, 1930. There had been no previous illness. Because of increasing edema, he was hospitalized in Iowa in December, 1930. Except for 
a brief return home at Christmas, 1930, he has been in the hospital up to the present time. Paracentesis abdominis was performed twice in the hospital at Iowa, and a permanent drain was left in the incision for $\mathbf{3 4}$ days after the second paracentesis. He had abdominal infections twice, which were diagnosed as peritonitis, and two attacks of pneumonia. At the time of the second abdominal infection, he had a bilateral non-suppurative parotitis which lasted for two weeks. At the Illinois Central Hospital, his edema remained intractable to every form of treatment. His best weight before illness had been 145 pounds. At the height of edema, he weighed 201 pounds, in spite of protracted malnutrition. One paracentesis was done during the period of study, but the ascites soon returned. He had a tonsillectomy done in 1929, for chronically infected tonsils. He had had scarlet fever and measles in childhood. His family history is insignificant, except for the simultaneous nephrotic picture in the other brother.

Physical examination. The patient was pallid, appeared ill and uncomfortable. His anasarca was so great as to make movement difficult and painful. His abdomen was tense because of fluid, the scrotum was a sac ás large as a grapefruit, and there was slight bilateral hydrothorax. The heart appeared normal, but the pulse was rapid. The temperature was slightly elevated at times. The eye grounds appeared edematous, but the blood vessels were normal.

Laboratory findings. R.B.C. were 4,070,000, Hemoglobin, 65 per cent. The urine showed from 20 to 25 grams of protein per day. Even when the daily excretion was only $600 \mathrm{cc}$., the urine contained very little pigment. There were many casts and some white cells. Red cells were found at times. The Wassermann reaction was negative. Gastro-intestinal, chest, and teeth $x$-rays were negative. The ethmoid and maxillary sinuses showed increased density. The phenolsulphonphthalein test showed 80 per cent excretion in two hours. Urea clearance was 50 per cent of normal. The basal metabolic rate was - 40 per cent, but when recalculated in terms of his ideal weight it was only -20 per cent. The blood chemistry showed a typical nephrotic picture.

Progress. Since the completion of the study two more paracenteses have been done. Southey's tubes were inserted for two days. By these measures, the weight was reduced from 201 to 140 pounds. With the aid of thyroid ingestion up to 15 grains daily, the patient has managed to stay at this weight, having only a moderate edema.

The authors wish to express their appreciation of the cooperation of the staffs of Presbyterian and Illinois Central Hospitals. They wish also to thank Miss Caroline M. Scotton for her assistance with the arrangement of the diets, and Dr. M. R. Freeland, who performed a number of the blood determinations.

\section{BIBLIOGRAPHY}

1. Leiter, L., Medicine, 1931, x, 135. Nephrosis.

2. Loeb, R. F., Atchley, D. W., Richards, D. W., Jr., Benedict, E. M., and Driscoll, M. E., J. Clin. Invest., 1932, xi, 621. On the Mechanism of Nephrotic Edema.

3. Starling, E. H., J. Physiol., 1896, xix, 312. On the Absorption of Fluids from the Connective Tissue Spaces.

4. Epstein, A. A., Am. J. Med. Sci., 1917, cliv, 638. Concerning the Causation of Edema in Chronic Parenchymatous Nephritis; Method for Its Alleviation. 
5. Moore, N. S., and Van Slyke, D. D., J. Clin. Invest., 1930, viii, 337. The Relationships between Plasma Specific Gravity, Plasma Protein Content, and Edema in Nephritis.

6. Peters, J. P., Bruckman, F. S., Eisenman, A. J., Hald, P. N., and Wakeman, A. M., J. Clin. Invest., 1931, x, 941. The Plasma Protein in Relation to Blood Hydration. VI. Serum Proteins in Nephritic Edema.

7. Widal, F., and Javal, A., J. de physiol. et de path. gén., 1903, v, 1199. La chlorurémie et la cure de déchloruration dans le mal de Bright. Etude sur l'action déchlorurante de quelques diurétiques.

8. Hoffman, W. S., J. Biol. Chem., 1931, xciii, 787. The Micro Determination of Fixed Base, Calcium, and Sulfates in Urine.

9. Jacobs, H. R. D., and Hoffman, W. S., J. Biol. Chem., 1931, xciii, 685. A New Colorimetric Method for the Estimation of Potassium.

10. Denis, W., J. Biol. Chem., 1922, lii, 411. The Determination of Magnesium in Blood, Plasma and Serum.

11. Fiske, C. H., and Subbarow, Y., J. Biol. Chem., 1925, 1xvi, 375. The Colorimetric Determination of Phosphorus.

12. Van Slyke, D. D., J. Biol. Chem., 1923, lviii, 523. The Determination of Chlorides in Blood and Tissues.

13. Tweedy, W. R., and Koch, F. C., J. Lab. and Clin. Med., 1928-29, xiv, 747. A Suggested Modification of the Kramer-Tisdall Method for Microchemical Estimation of Ionizable Calcium in Blood Plasma.

14. Hoffman, W. S., Proc. Soc. Exper. Biol. and Med., 1933, xxx, 834. The Determination of Serum Total Base.

15. Fiske, C. H., J. Biol. Chem., 1922, li, 55. A Method for the Estimation of Total Base in Urine.

16. Peters, J. P., and Van Slyke, D. D., Quantitative Clinical Chemistry, Vol. II. Methods. Williams and Wilkins Co., Baltimore, 1932.

17. Stadie, W. C., and Ross, E. C., J. Biol. Chem., 1925, 1xv, 735. A Micro Method for the Determination of Base in Blood and Serum and Other Biological Materials.

18. Folin, O., and Wu, H., J. Biol. Chem., 1919, xxxviii, 81. A System of Blood Analysis.

19. Koch, F. C., and McMeekin, T. L., J. Am. Chem. Soc., 1924, xlvi, 2066. New Direct Nesslerization Micro-Kjeldahl Method and a Modification of the Nessler-Folin Reagent for Ammonia.

20. Howe, P. E., J. Biol. Chem., 1921, xlix, 109. The Determination of Proteins in Blood-A Micro Method.

21. Van Slyke, D. D., and Cullen, G. E., J. Biol. Chem., 1917, xxx, 289. Studies in Acidosis. I. The Bicarbonate Concentration of the Blood Plasma; Its Significance, and Its Determination as a Measure of Acidosis.

22. Hoffman, W. S., and Jacobs, H. R. D., In Press. The Partition of Potassium between Serum and Corpuscles in Health and in Disease.

23. Keutmann, E. H., and McCann, W. S., J. Clin. Invest., 1932, xi, 973. Dietary Protein in Hemorrhagic Bright's Disease. I. Effects upon the Course of the Disease with Special Reference to Hematuria and Renal Function.

24. Gamble, J. L., Ross, G. S., and Tisdall, F. F., J. Biol. Chem., 1923, 1vii, 633. The Metabolism of Fixed Base during Fasting.

25. Albright, F., and Bauer, W., J. Clin. Invest., 1929, vii, 465. The Action of Sodium Chloride, Ammonium Chloride, and Sodium Bicarbonate on the Total Acid-Base Balance of a Case of Chronic Nephritis with Edema. 
26. Gamble, J. L., Blackfan, K. D., and Hamilton, B., J. Clin. Invest., 1925, i, 359. A Study of the Diuretic Action of Acid Producing Salts.

27. Linder, G. C., Quart. J. Med., 1927, xx, 285. The Effect of Mineral Acid on Acid-Base Regulation in Health and in Nephritis.

28. Albright, F., and Ellsworth, R., J. Clin. Invest., 1929, vii, 183. Studies on the Physiology of the Parathyroid Glands. I. Calcium and Phosphorus Studies on a Case of Idiopathic Hypoparathyroidism.

29. O'Donnell, W. S., and Levin, S. J., J. A. M. A., 1931, xcvi, 837. The Treatment of Edema. Effect of Calcium Gluconate on Edema in Children. 